Arq. Bras. Med. Vet. Zootec., v.65, n.3, p.749-756, 2013

\title{
The peculiarities of the masticator muscles in rodents
}

[Particularidades da masculatura mastigatória dos roedores]

\author{
C. Spataru, M. Spataru, V. Vulpe, M. Lazar
}

Faculty of Veterinary Medicine - Iasi, Romania

\begin{abstract}
Comparative research concerning masticatory musculature in squirrel, muskrat and rabbit, take into account the emphasizing and morphofunctional interpretation of the osteomuscular particularities involved in the prehension and mastication processes. The development of the coronoid process on the muskrat and squirrel demonstrates the growing of the force when raising the mandible by increasing the action force attached to the temporal muscle, with insertion on the coronoid process. In comparison with that, in the case of rabbits, both the coronoid process and the temporal muscle are reduced. From a philogenetic point of view, it has been found that the species that have the articular condyle lowered at or under the level of the dental tables (carnivores) present a greater pressure force between the dental tables. Analyzing this aspect of the rodents taken into discussion, we noticed the lowering of the articular condyle up to the inferior molars' plane, in the case of squirrels and muskrats, but through obliquity, namely through cranial caudal and dorsoventral movement. This peculiarity is emphasized through the analysis of the angle formed by the axis of the mandible recurved branch (passing through the mandibular condyle) with the axis of the horizontal branch of the mandible, where it was noticed that along with the increase in the angle formed by the two axes, which becomes an obtuse 160 degree angle on the squirrel and 130 degrees on the muskrat, there is also a lowering of the articular condyle up to the molar level, while in the case of carnivores, the lowering of the condyle is done without the modification of the angle between the two axes, which measures approximately 90 degrees.
\end{abstract}

Keywords: squirrel, muskrat, rabbit, bone, muscle, skeleton

\section{RESUMO}

Investigações comparativas com respeito à musculatura mastigatória do esquilo, do rato-almiscarado $e$ do coelho buscam o realçamento e a interpretação morfo-funcional das particularidades do sistema dos músculos esqueléticos envolvido no processo de agarramento e mastigação. $O$ desenvolvimento do processo coronoide no rato-almiscarado e no esquilo demonstra o aumento da força no levantamento da mandíbula por meio do aumento do braço da força de ação do músculo temporal com inserção sobre o processo coronoide, em comparação com os leporídeos, que têm tanto o processo coronoide como o músculo temporal mais reduzidos. Do ponto de vista filogenético, observa-se que as espécies que apresentam o côndilo articular baixado igual ou inferior ao nível das placas dentárias (carnívoros) apresentam uma força de pressão maior entre as placas dentárias. Em relação aos roedores estudados, nota-se a descida do côndilo articular perto do plano dos molares inferiores no esquilo e no ratoalmiscarado, mas por meio da obliquidade, isto é, por meio do movimento do côndilo articular da borda craniana e dorsoventral. Esta particularidade evidencia-se em virtude do ângulo formado pelo eixo do ramo dobrado da mandíbula (que atravessa o côndilo mandibular) junto ao eixo do ramo horizontal da mandíbula, resultando no aumento do valor do ângulo formado pelos dois eixos, que se tornam obtusos a $160^{\circ}$ no esquilo e a $130^{\circ}$ no rato-almiscarado, em função da descida do côndilo articular quase ao nível do plano dos molares, em comparação com os carnívoros, nos quais a descida do côndilo realiza-se sem a modificação do ângulo formado pelos dois eixos de, aproximadamente, 90 graus.

Palavras -chave: esquilo, rato-almiscarado, coelho, osso, músculo, esqueleto

Recebido em 1 de novembro de 2011

Aceito em 6 de março de 2012

E-mail: cspatarufmv@yahoo.com 


\section{INTRODUCTION}

The researches undertaken on squirrel (Sciurus vulgaris), muskrat (Ondatra zybethica) and rabbit (Lepus europaeus) rodents take into account the emphasizing and interpretation of morphofunctional peculiarities of the masticatory musculature, which, by its development, form and act on the osteoligamentary system to determine some morphological modifications attached to the type of movement and force of action consecutive to the environment and feeding habits of the animal (Messa, 1980, Moiller, 1983, Kenward and Hodder, 1998, Gurnell et al., 2002).

The studies undertaken on the prehension apparatus of the rodents showed that there are major differences concerning the conformation of the jaw bone and of the mandible (Weijs and Dantuma, 1980; Crossley, 1995), these being determined by the peculiarities of the prehension and triturating of food, a consequence of each species' adaptation to the food type (Rinker,1954).

The squirrel is a rodent with an extremely varied area of living, from plain forests to conifers (Peterka, 1936; Emry and Thorington, 1984; Wauters et al., 1992), being adapted to both trees and terrestrial areas (Moiller, 1982). Its food consists in conifer seeds, especially from pine trees, nut trees, hazelnut trees, beech nut trees, acorn trees, berries, springs, leaves or tree barks, but also very small animals, insects, baby birds and eggs, and animal bones (Gurnell, 1983; Wauters et al., 1992).

The muskrat is a mammal rodent that lives in both an aquatic and terrestrial environment (Messa, 1980; Toivonen and Merilainen, 1980). The muskrat lives on the shores of flowing and standing freshwaters, or swamps, where it eats land and submerged aquatic plants, but also animal food like shells, frogs, crustaceans etc. Thus, the constituent elements of the prehension and mastication apparatus harmonize with and adapt to these two different types of nourishment, for rodents and for carnivores, keeping the general features of a rodent. But the development of the chewing muscles demonstrates their special implication in the process of mechanical processing of food, taking intermediary features between the rodent and the carnivore types.

Lepus europeaus is a terrestrial rodent eating grass, springs, young tree barks and fodder that would need less force in sectioning and grinding them (Rinker, 1954).

\section{MATERIAL AND METHODS}

The studies were undertaken on corpses of the three species of rodents of different sexes and ages. The seven shot muskrat corpses came from the hydrographic basins of Moldova, and were preserved with formalin. The 14 corpses of Sciurus vulgaris came to us from car and hunting accidents happened in Moldavian coniferous and decidous forests, as well as in the parks of Iaşi city. The 13 corpses of Leporidae belong to both domestic (Lepus europaeus) and field rabbits (Oryctolagus cuniculus) and we got them from among the sacrificed or shot ones.

In preparing the bone pieces we proceeded to the boiling and/or scraping of the adjacent tissues from the bones. After this manual labour the form and length of the osteoligamentary structures or of the eminences and depressions that constitute areas of insertion and action levers of the muscles, or appear as a consequence of the bones pressure over muscles were identified. This pressure on the bone leads to its resorption, which determines the emergence of cavities, hollows, apertures etc. The muscles were analyzed by undertaking dissections on fresh or preserved (with formalin 5\% concentration) corpses.

A stratigraphic and regional dissection was done, following the muscle position, the preparation of origins and insertions, and the relation of each muscle with the neighbouring ones. After identifying the muscles and considering their development, we established their degree of implication in undertaking a movement, in relation to the effect produced by both the agonistic and antagonistic muscles. Comparative measurements on angular and coronoid processes, the height of the articular condyle compared to the inferior tables of dental planes, as well as the angle between the axis of the recurved branch of the mandible and the axis of the horizontal part, constituted important morphological criteria in establishing the 
pressure force that masticatory muscles exert among the dental tables during contraction.

All the identified peculiarities were photographed with a digital Olympus camera and processed in Adobe Photoshop.

\section{RESULTS AND DISCUSSION}

A common point for all rodents is that at the level of the skull (that was noticed while analyzing the squirrel) the obvious development of the incisive alveolar processes, and the abrasive edge of the incisors having a chisel aspect is observed (Peterka, 1936; Ardran et al., 1958; Crossley, 1995). The molars, on the other hand, have an intermediary aspect between the lophodont and the bunodont type, the molar ridges having an irregular aspect, and resembling to some tubercles (Emry and Thorington, 1984) (Figure 1).

A reduction of the diastema space in comparison with what happens in the case of rabbits and muskrats (Peterka, 1936) was also remarked.

On the squirrel the mandible is particularized by the development of the angular process (Figures $5,6,8)$, by the high coronoid process with a triangular aspect (Figures 1, 6), and by the lowering, up to the mandibular dental plane of the articular condyle, through caudo-ventral movement. The angular process is wide, of quadrilateral form, and presents, on the lateral face, the continuation of the masseter fossa, delimited by a crest with a curved aspect (Figure 1).

It could also be noticed that on the medial face of the angular process there was a deep pterygoid fossa. The articular condyle is particuralized by an emphasized caudal obliquity, which makes the formig of a 160 degrees angle between the axes of the condyle and the horizontal part of the mandible (Figure 1) possible.

In what the skull muscles are concerned, in the case of rodents, we found a reduction or the absence of most of the mimic muscles (Woods, 1972; Thorington and Darrow, 1996) from the dorsal part of the skull and the reduction of the muscles placed around the nasal and oral orifices, the most developed of them being the buccinator muscle (Figure 2).
On the squirrel one can notice the development of the masticatory musculature (Thorington and Darrow, 1996). The masseter muscle is quite developed, being formed out of three portions: superficial, infra orbital and zygomatic (Figure 2 ), well shaped and with the fibres oriented in different plans and angles (Figure 3).

The superficial portion has its aponeurotic origin in a powerful and wide tendon that can be found on the facial spina (Figure 2, 3). The musculoaponeurotic fibres have an emphasized ventro aboral obliquity, and they continue with a massive muscular belly that can be seen on the angle and ventral edge of the angular process of the mandible (Figures 3, 4). By the extremely oblique position of the muscular fibres they mainly act as a propeller of the mandible, using as a set point the facial spina, propulsing the mandible. The almost horizontal position of the muscular fibres and the long tendon of origin represent adaptation factors of the prehension apparatus for food transport, the muscle contraction allowing food to be kept in the oral cavity for a long time without the manifestation of muscular tiredness.

The zygomatic portion (Figure 2) has two layers of fibres, a superficial and a deep, placed under the superficial part of the muscle. The fibres are oriented dorso ventrally, have an aboral inclination and are found on the ventral edge of the recurved branch of the mandible. The deep portion has its origin on the medial face of the zygomatic arcade (Figure 3), the fibres have a ventro-aboral orientation and are found among the multiple tendinous interstices (Figures 4, 5) on the dorso-lateral edge of the angular process (Figure 5).

The infraorbital portion (Figure 2) has its origin on the facial crest and its insertion on the masseter fossa (Figures 5, 6), which has an area with an oval aspect that is delimited by a bone crest (Figure 4). The massive muscular belly, from the origin towards the insertion, passes through the orbital fossa (Figure 5) that looks like a deep slot due to the muscle pressure on the jaw surface, directing the muscle action towards elevation and propulsion movements of the mandible (Figure 5).

The temporal muscle (Peterka, 1936) on the squirrel is made out of two portions, anterior 
(Figures 3, 6) and posterior ones (Figures 3, 6). The anterior portion, more reduced than the other, has a triangular aspect (Figure 6). Its origin is on the parietal dorsal line, caudal to the orbit, and the insertion is on the anterior edge of the coronoid process (Figure 6). The deep portion has its origin in the temporal fossa as a whole, up to the external occipital crest. It has a flabelliform aspect, the fibers being inserted on top of the coronoid process (Figure 6).

In comparison with other rodents, on the squirrel it can be found only the digastric portion (Figure 3) of the occipital-mandibular muscle (Rinker, 1954). This muscle has its origin on the paracondylian process reduced to a tubercle, and caudo-ventral edge of the tympanic bubble (Figure 8), and the muscular belly is continued with a thick and powerful intermediary tendon (Figure 7, 8).

The distal muscular bellies of the symmetrical digastric muscles merge into the intermadibular space and are inserted on the mileen line and on the geneen crest of the mandible, together with the milohioidien and geniohioidien muscles with which they make a common corpus (Figure 7,8). The dorso-ventral position of the muscle, the intermediary tendon and the position under the form of an arc, allow the ample extension of the temporal mandibular articulation, producing, on the other hand, ample retropulsion movements.

The mandibular angle of 160 degrees, resulting from the obliquity of the articular condyle and its placement near the mandible molar plane (Figure 1) has as an effect the growing of the force between the dental tables directly proportional with the growing of the force arm of the raising muscles of the mandible (m. masseter, $\mathrm{m}$. temporalis).

On the muskrat the dentition has a lophodent aspect with sharp crests oriented transversally, a peculiarity of this species being the round aspect of the abrasive face of the superior molars (Toivonen and Merilainen, 1980; Spataru and Spataru, 2003; Spataru, 2005). The recurved branch of the mandible has a tricuspid end, resembling that of the squirrel, and the obliquity of the articular condyle towards the horizontal branch of the mandible is approximately 130 degrees (Figure 9). The coronoid process is developed (Figures 9, 12), prolonged, oblique and caudally oriented. The sharp angular process (Figure 12) reaches the caudal plan of the articular condyle. The articular condyle exceeds much in height the level of the inferior dental tables (Figure 9-a- the axis of the horizontal part of the mandible, $b$ - the axis of the mandible condyle, $h$ - the height of the condyle in comparison with the molar plane). When the plane of the articular surface of the mandibular condyle is raised, the force arm is reduced and the amplitude of the flexion movement of the mandible grows. Nevertheless, the reduction of the force is replaced by the development of the muscular bellies of the temporal and masseter muscles.

On the muskrat, as in the case of the squirrel, the masseter muscle is made up of three portions: superficial, zygomatic and infraorbital (Figure 10). The superficial portion has its origin (through a long tendon) on the facial tubercle (Figure 10), and the muscular belly is inserted on the ventral third of the mandible and on the whole angular process (Figures 11, 12). This portion presents the fibers oriented obliquely aborally and through contraction they produce the propulsion of the mandible. The zygomatic portion (Figure 10) has its origin all along the zygomatic arcade up to the jaw, and its insertion in the masseter fossa (Figure 12), where it occupies the lateral face of the mandible, in dorsal position towards the superficial portion (Figure 11). The fibers present a ventral orientation that indicates force in elevating the mandible, an efficient action in the process of sectioning (Woods, 1972). 


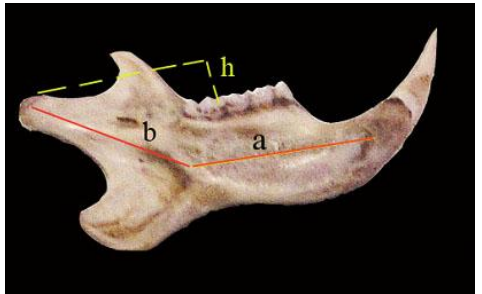

Figure 1. Squirrel mandible, medial view.

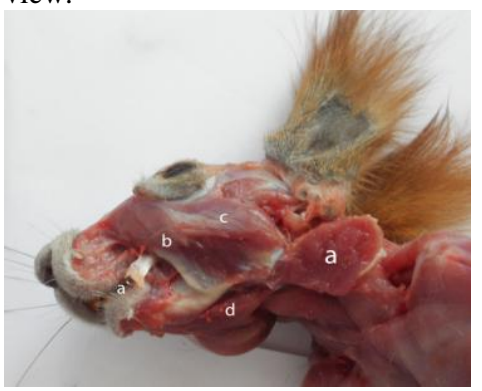

Figure 4. The masseter muscle on the red squirrel, deep leyer.

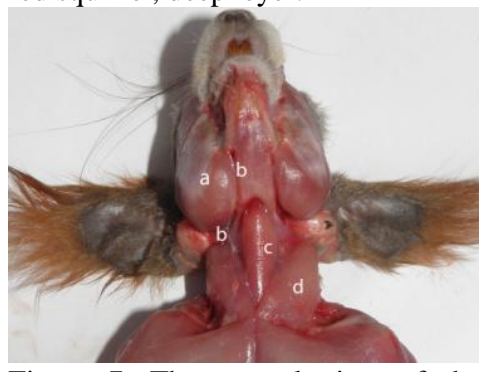

Figure 7. The ventral view of the head muscles on the red squirrel.

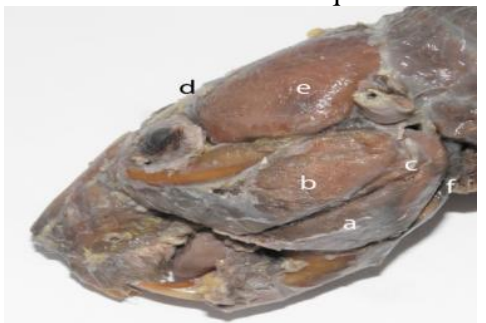

Figure 10. The muscles of the head on the muskrat.

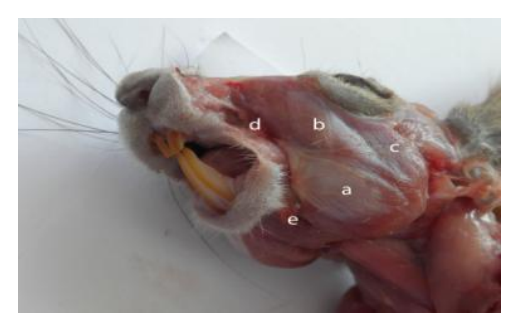

Figure 2. The masseter muscle on the red squirrel.

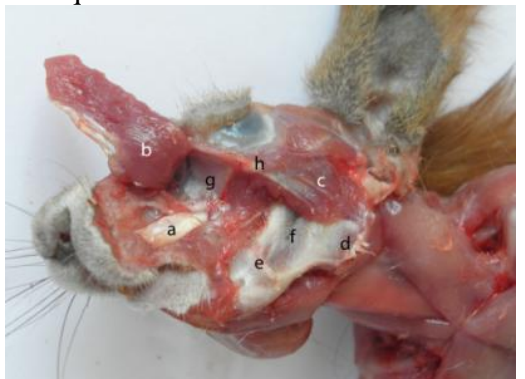

Figure 5. The deep parts of the masseter muscle on squirrel.

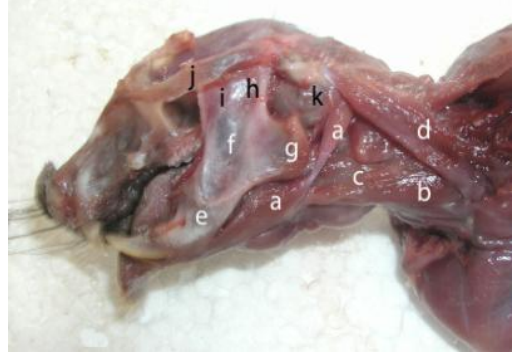

Figure 8 . The ventral head muscles on the red squirrel.

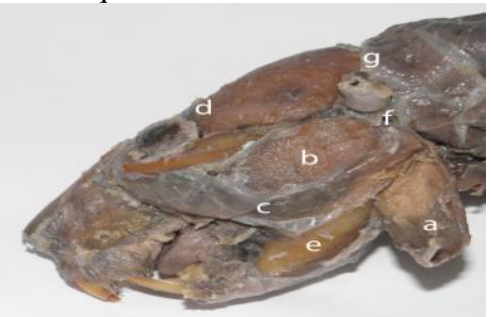

Figure 11 . The masticatory muscles on the muskrat.

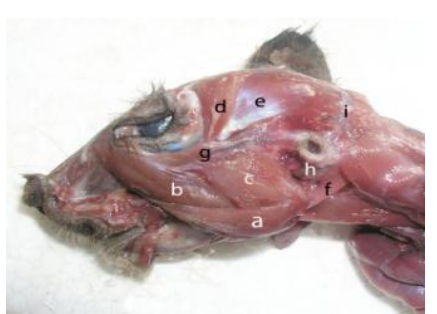

Figure 3. The masticatory muscles on the red squirrel.

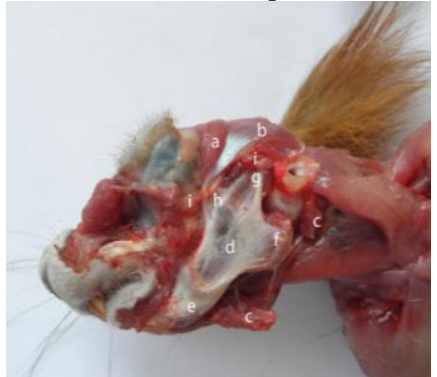

Figure 6. The temporal muscle on the red squirrel.

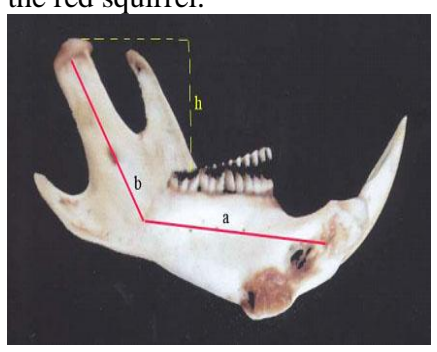

Figure 9. Mandible on the muskrat, medial view.

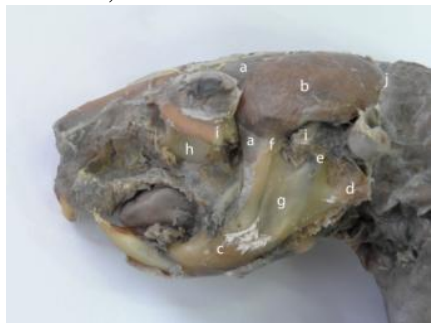

Figure 12. The deep muscles of the muskrat's head.
The infraorbital portion (Figure 10), as in the case of the squirrel, has its origin on the facial tubercle of the jaw, the powerful muscular belly passing through the infraorbital fossa to be inserted on the masseteric crest (Figure 12). This very portion of the masseter, with the fibres oriented slightly obliquely oral - aborally, on the muskrat, as well as on the squirrel, determines the propulsion of the mandible, an efficient and specific action of the rodents in the process of food grinding (Rinker, 1954).
The temporal muscle is much more developed in the case of the muskrat than in the case of the squirrel and rabbit (Spataru and Spataru, 2003). The muskrat has a powerful temporal muscle, with two very developed portions (Figures 10, 12).

The posterior portion (Figure 12) is inserted both on the articular condyle (Figure 12) and on the posterior edge of the corono-condylian process 
of the mandible (Figure 12). The anterior portion (Figure 12) passes over the orbital process of the frontal that it transforms into muscular trohlea as to be inserted on the anterior edge of the coronocondylian process (Figure 12), determining, by contraction, the raising of the mandible at the same time with its propulsion movement, due to the change in the action direction produced by its trajectory anterior to the orbit.

In the case of the muskrat, the occipitomandibular muscle is massive (Figure 10), it has its origin on the paracondylian process of the occipital, the muscular fibers are obliquely distributed antero-ventrally, with an insertion all along the caudal medial edge of the mandible, and on the angular process (Rinker, 1954; Spataru and Spataru, 2003). Through its insertion on the caudal edge of the mandible, posterior to the temporal mandibular articulation, which constitutes the point of support of the mandible, and by contraction, the muscle pulls the mandible producing its extension.

The leporids are rodents whose dentition is of a lophodont type (Ardan et al., 1958; Crosseley, 1995). In what the mandible is concerned, in the case of rabbits one will notice the raising of the mandibular condyle much above the planes of the molar tables, and the reduction of the coronocondylian process, with the thickening of the anterior edge of the recurved branch of the mandible (Ardan and all, 1958) (Figure 13). The mandibular condyle has a prolonged aspect in a longitudinal plan. All these peculiarities characterize the mastication by propulsion and retropulsion movements. The angle made by the axis of the recurved branch and the axis of the horizontal branch of the mandible is 120 degrees (Figure 13).

Considering the origin, the plan and the orientation of the muscular fibres, the masseter muscle of the rabbit presents two portions: a superficial (Figure 14) zygomatic part (Figures $14,15)$ and deep portions (Figures 14, 15, 16). The superficial portion (Figure 14) is the most developed one, having the fibres disposed in an oblique dorso-ventral way, with an aponeurotic origin on the anterior half of the facial crest and on the facial tubercle, and with an insertion on most of the masseter fossa and angular process (Figures 16, 17). Following the fibres orientation, by contraction, we can observe the raising and propulsion of the mandible (Weijs and Dantuma, 1980).

The zygomatic portion of the masseter muscle (Figure 15) has the fibres disposed almost vertically, between the zygomatic crest and the masseter fossa. It has a role in generating the force between the dental tables by raising the mandible (Weijs and Dantuma, 1980).

The deep portion of the masseter muscle (Figures $14,15,16)$ is reduced, the muscular fibers are disposed obliquely, ventro-cranial, having their origin on the posterior third of the facial crest, and the insertion at the basis of the articular condyle of the mandible, above the angular process. By contraction, it produces the retropulsion of the mandible.

The temporal muscle (Figure 14) is formed by the two portions, superficial and deep (Figure 17). The superficial portion is reduced (Figure 17), it has the origin in the temporal fossa, it continues with a long tendon that passes over the zygomatic process of the temporal, as to be inserted on the corono- condylian process of the mandible (Figure 17).

The deep portion of the temporal muscle is made up of two groups, anterior and posterior. The anterior portion has the origin in the rostral portion of the temporal fossa, and the insertion on the anterior edge of the coronoid process (Figure 17). The deep portion (Figure 17) has its origin in the temporal fossa and the insertion on the medial face of the mandibular condyle (Figure 17). Through its insertion on the medial face of the articular condyle of the mandible, the deep portion may also determine slight lateral movements of the mandible (Weijs and Dantuma, 1980).

In the case of squirrels and muskrats, the lowering of the mandible is mainly done by the occipital - mandibular muscle (Figure 18). In the case of the rabbit, the occipito-mandibular muscle is characterized by a long and powerful tendon of origin continued with a developed muscular belly and with insertion on the medial face of the horizontal branch of the mandible (Figure18). The lowering or retropulsion of the mandible is produced by the action of the muscle over the mandible (Ardan et al., 1958). 


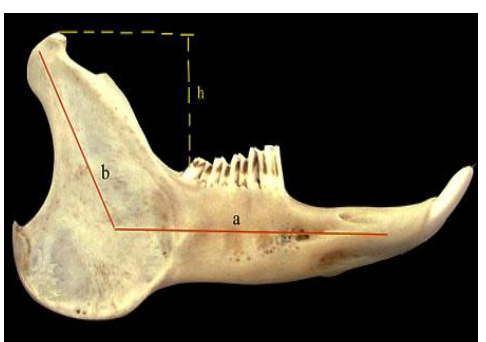

Figure 13. The mandible on the rabbit, lateral view.

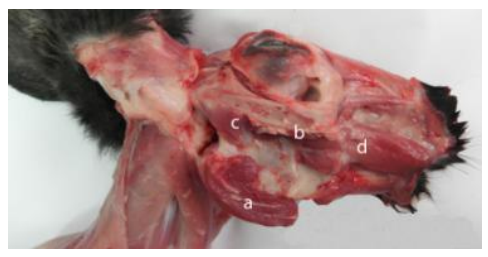

Figure 16. The deep muscles of the rabbit head.

\section{CONCLUSIONS}

By analyzing the angle formed by the axis of the recurved branch (corresponding with the axis of the articular condyle) with the axis of the horizontal branch of the mandible, namely 160 degrees in the case of squirrels, 130 degrees in the case of muskrats and 120 degrees in the case of rabbits, the form and development of the coronoid process, which represents the force arm for the temporal muscle, are determined by the development and way of action of the temporal muscle. On the squirrel, it is reduced and the coronoid process is also reduced having a triangular form, on the leporids the muscle is undeveloped, and the coronoid process is reduced to a spine placed under the plane of the articular condyle or higher and caudally oriented on the muskrat, where the temporal muscle is very developed. The angular process appears to have moved caudally to a great extent, being separated by a deep slot (on the squirrel and muskrat), and offers enough place for the insertion of the superficial portion of the masseter muscle. On the rabbit, the angular process appears to be round, and as a continuation of the ventral edge of the recurved branch of the mandible. On these two species, squirrel and muskrat, the greater force between the superior and inferior dental tables produced by the masseter muscle is amplified also by the caudal movement of the teeth ridges belonging to the inferior molars and their placement on the medial face of the mandible.

\section{ACKNOWLEDGMENTS}

The paper is published through the CNCSISUEFISCDI grant, on 1112/2009, whose director is Constantin Spataru.

\section{REFERENCES}

ARDRAN, G.M.; KEMP, F.H.; RIDE, W.D.L. A radiographic analysis of mastication and swallowing in the domestic rabbit: Oryctolagus cuniculus (L.). Proc. Zool. Soc. London, v.130, p.257-274, 1958

CROSSLEY, D. Clinical aspects of lagomorph dental anatomy: The rabbit (Oryctolagus cuniculus). J. Vet. Dent., v.12, p.137-140, 1995.

EMRY, R.J.; THORINGTON Jr., R.W. The tree squirrel Sciurus (Sciuridae, Rodentia) as a living fossil. In: ELDRIDGE, N; STANLEY, S.M. (eds.). Living fossils. New York: Springer-Verlag. 1984, p.23-31.

GURNELL, J. Squirrel numbers and the abundance of tree seeds, Mamm. Rev., v.13, p.133-148, 1983 
GURNELL, J.; MIKE, J.; PETER, W.W. et al. Conserving red squirrels (Sciurus vulgaris): mapping and forecasting habitat suitability using a Geographic Information Systems Approach, Biol. Conserv., v.105, p.53-64, 2002.

KENWARD, R.E.; HODDER, K.H. Red squirrels (Sciurus vulgaris) released in conifer woodland: The effects of source habitat, predation and interactions with grey squirrels (Sciurus carolinensis). J. Zool., v.244, p.23-32, 1998.

MESSA, D.J. Population Dynamics of Sacramento Valley Muskrats. Federal Aid in Wildlife Restoration Project W-54-R-11, Job II1.6. Califórnia:California State University, 1980. p.17.

MOILLER, H. Foods and foraging behavior of red (Sciurus vulgaris) and gray (Sciurus carolinensis) squirrels. Mamm. Rev., v.13, p.8198, 1983.

PETERKA, H.E. A study of the myology and osteology of tree sciurids with regard to adaptation to arboreal, glissant and fossorial habits. Trans. Kans. Acad. Sci., v.39, p.313-332, 1936.

RINKER, G.C. The comparative myology of the mammalian genera Sigmodon, Oryzomys, Neotoma, and Peromyscus (Cricitinae), with remarks on their intergeneric relationships. Univ. Mich. Misc. Publ. Mus. Zool., v.83, p.1-124, 1954.
SPATARU, M.; SPATARU, C. Particularităţi anatomice ale craniului la bizam. Simp. Ştiinţ. Chişinău - R. Moldova, p.44-47, 2003.

SPATARU, M.; SPATARU, C. Aspecte privind musculatura masticatoare la bizam. Lucr. Ştiint. seria Med. Vet. Iasi, v.46, p.51-54, 2003.

SPATARU, M. Anatomic differences between the young and adult muskrat's skulls, Lucr. Stiint. seria Med. Vet. Iaşi, v.48, p.273-276, 2005.

THORINGTON, R.W.; DARROW Jr., K. Jaw muscles of OldWorld squirrels. J. Morphol., v.230, p.145-165, 1996.

TOIVONEN, H.; MERILAINEM, J. Impact of the muskrat (Ondatra zibethica) on aquatic vegetation in small Finnish lakes. Develop. in Hydrobiol., v.3, p.131-138, 1980.

WAUTERS, L.; SWINNEN, C.; DHONDT, A.A. Activity budget and foraging behaviour or red squirrels (Sciurus vulgaris) in coniferous and deciduous habitats. J. Zool., v.227, p.71-86, 1992.

WEIJS, W.A.; DANTUMA, R. Functional Anatomy of the masticatory apparatus in the rabbit (Oryctolagus cuniculus). Netherlands J. Zool., v.31, p.99-147, 1980.

WOODS, C.A. Comparative myology of the jaw, hyoid, and pectoral appendicular regions of New and Old World hystricomorph rodents. Bull. Am. Mus. Nat. Hist., v.147, p.115-198, 1972. 